\title{
HAKEKAT ASESMEN AUTENTIK DAN PENERAPANNYA DALAM PEMBELAJARAN BIOLOGI
}

\author{
Yuni Pantiwati \\ Universitas Muhammadiyah Malang \\ yuni_pantiwati@yahoo.co.id
}

\begin{abstract}
ABSTRAK
Asesmen merupakan proses mencari informasi. Asesmen dapat dilakukan tanpa evaluasi, tetapi evaluasi tidak dapat dilakukan tanpa asesmen. Asesmen autentik merupakan suatu penilaian yang dilakukan melalui penyajian atau penampilan oleh siswa dalam bentuk pengerjaan tugas-tugas atau berbagai aktivitas tertentu yang langsung mempunyai makna pendidikan. Pembelajaran Biologi mejadi bermakna bila menggunakan asesmen yang tepat yaitu asesmen autentik karena tidak cukup memahami pengatahuan Biologi saja tetapi dituntut dapat memecahkan masalah dalam kehidupan sehar-hari. Pendekatan yang digunakan dalam mempelajari Biologi melalui Pendekatan Keterampilan Proses, pendekatan ini juga menuntut penilaian yang autentik.
\end{abstract}

\section{Kata Kunci: Asesmen Autentik, Biologi, Pendekatan Keterampilan Proses}

\section{PENDAHULUAN}

Melakukan penilaian merupakan salah satu tugas guru selain menyusun program pembelajaran dan mengimplementasikannya di dalam kelas. Guru juga harus dapat menetapkan apa yang dapat diperoleh atau dicapai dari proses pembelajaran yang telah diselenggarakan. Selanjutnya guru harus dapat menetapkan apakah program yang ia rencanakan dapat terlaksana sesuai harapan, dalam arti bahwa kompetensi yang dikembangkan pada diri siswa sesuai dengan harapan. Semua ini dapat diketahui dan terjawab, jika guru melakukan asesmen dan evaluasi dengan baik. Hal ini sesuai pendapat Johnson (2002) bahwa asesmen dapat dilakukan tanpa evaluasi, tetapi evaluasi tidak dapat dilakukan tanpa asesmen. Asesmen sangat berperan dalam menentukan arah pembelajaran dan kualitas pendidikan. Menurut Atkin, Black, \& Coffey (2001) bahwa ada beberapa prioritas dalam pembaharuan pendidikan, seperti a) inkuiri saintifik dalam isi dan pendekatan pembelajaran, b) asesmen untuk memperbaiki proses pembelajaran, c) peran teknologi dalam kurikulum, d) pemilihan dan identifikasi materi pembelajaran yang efektif sesuai dengan standar yang ditetapkan, dan e) mengembangkan program pendidikan yang koheren untuk semua jenjang pendidikan. Pendapat tersebut menunjukkan bahwa untuk saat ini dibutuhkan asesmen yang dapat memperbaiki proses pembelajaran

Zaamroni (2004) mengemukakan bahwa evaluasi akan merupakan kebijakan yang dapat meningkatkan kualitas pendidikan, apabila: a) memberikan umpan balik yang efektif kepada siswa, b) mendorong aktivitas siswa dalam proses pembelajaran mereka sendiri, c) umpan balik bagi guru untuk melakukan penyesuaian dalam melaksanakan pembelajaran, d) memahami pengaruh evaluasi terhadap motivasi siswa dan kepercayaan diri mereka, dan e) alat bagi siswa untuk melakukan monitoring dan koreksi diri mereka sendiri. Dengan demikian apabila siswa dapat mengetahui kemajuan dan perkembangan dirinya, siswa dapat mengatur belajarnya dengan menentukan langkah-langkah kegiatan belajar berikutnya sehingga kondisi ini memungkinkan siswa untuk belajar secara 
terus menerus dan mendorong terlaksananya life long learning.

Terlaksananya life long learning tentunya tidak terlepas dari peran guru dalam pembelajaran karena perilaku guru dalam mengajar dapat mempengaruhi perilaku siswa dalam belajar. Sedang perilaku guru dalam melaksanakan proses belajar mengajar dipengaruhi oleh sistem dan teknik evaluasi., sebagaimana slogan "Bagaimana evaluasi dilakukan begitulah guru mengajar". Selanjutnya menurut Zamroni (2004) perilaku guru dan siswa dalam proses belajar mengajar harus berubah, perubahan ini akan menjadi kenyataan apabila sistem evaluasi sekolah juga berubah. Tanpa perubahan dalam evaluasi tidak akan ada perubahan dalam proses belajar mengajar. Namun merubah perilaku guru pun tidak mudah, mengingat merubah paradigma seseorang bukan sesuatu yang mudah dilakukan.

Berdasarkan pengamatan dilapangan menunjukkan bahwa sistem penilaian yang digunakan para guru umumnya paper and penci test karena mereka menilai cukup praktis dalam arti tidak membutuhkan tenaga, biaya, dan waktu yang banyak. Sebaliknya jika menggunakan asesmen autentik membutuhkan tenaga, biaya, dan waktu yang lebih banyak, sehingga guru enggan menggunakannya. Pemikiran dan perilaku seperti inilah yang dapat menghambat tercapainya kualitas pembelajaran dan pendidikan. Hasil penelitian Pantiwati (2013) tentang profil sistem penilaian oleh guru juga menunjukkan bahwa tes tulis bentuk obyektif mendominasi intrumen pengukuran hasil belajar siswa, selain itu respon siswa juga mendukung bentuk tes tertulis dibanding bentuk asesmen yang lain. Siswa juga tidak menyukai asesmen melalui analisis kritis artikel yang menuntut siswa berikir tingkat tinggi. Demikian juga siswa tidak menyukai asesmen bentuk portofolio.

Hal senada juga diungkapkan oleh Umar (2004) bahwa keadaan lulus 100\% siswa pada ujian nasional di suatu sekolah juga berdampak buruk pada perilaku mengajar guru. Guru umumnya merasa sudah aman dan selesai tugasnya jika telah melaksanakan semua kewajiban kurikuler meskipun murid-muridnya tidak memahami apa yang diajarkan. Dengan demikian pendidikan yang tidak menghasilkan lulusan yang bermutu bukanlah merupakan investasi SDM (sumber daya manusia), melainkan pemborosan beaya, tenaga dan waktu.

Oleh karena itu perlu dipikirkan metode yang tepat dalam melakukan evaluasi agar penilaian yang dilakukan pada siswa dapat memberikan informasi yang utuh tentang siswa. Kalau seorang siswa dikatakan berhasil dalam belajarnya, maka keberhasilan itu haruslah diukur dengan alat ukur yang sesuai dengan tujuan belajarnya atau kompetensi yang harus dicapainya. Dengan kata lain informasi yang diperoleh dari asesmen harus komprensif dan telah dilakukan pada saat-saat yang tepat selama dan setelah siswa belajar. Artinya pengukuran harus dilakukan di sepanjang proses belajar yang dijalani siswa. Prinsip inilah yang disebut dengan asesmen berkelanjutan. Asesmen ini dilaksana-kan secara terpadu dengan kegiatan belajar mengajar sehingga disebut sebagai penilaian berbasis kelas (PBK). Penilaian kelas merupakan suatu proses yang dilakukan melalui langkah-langkah Hubungan Pengukuran, Penilaian, dan Evaluasi

Penilaian kelas merupakan suatu proses yang dilakukan melalui langkahlangkah perencanaan, penyusunan alat penilaian, dan pengumpulan informasi melalui sejumlah bukti yang menunjukkan pencapaian hasil belajar peserta didik, pengolahan, dan penggunaan informasi. Penilaian kelas dilaksanakan melalui berbagai cara, seperti penilaian unjuk kerja (performance), penilaian sikap, penilaian tertulis (paper and pencil test), penilaian proyek, penilaian produk, penilaian melalui kumpulan hasil kerja/karya peserta didik (portofolio), dan penilaian diri. Penilaian 
dilakukan sebelum pengukuran karena pengukuran (measurement) merupakan pemberian angka pada objek atau peristiwa menurut aturan yang memberikan arti kuantitatif (Wiersma dan Jurs,1990).

Selanjutnya Grounlund

menyatakan pengukuran adalah proses untuk memperoleh deskripsi angka tentang derajat karakteristik tertentu yang dimiliki oleh individu. Pengumpulan informasi ini dilakukan selain menggunakan tes, juga dilakukan dengan mengobservasi siswa ketika sedang belajar, mewawancarai, atau memeriksa produk siswa. Guru diberi kebebasan untuk memilih teknik pengujiannya yang dirancang menyangkut penentuan jenis tagihan, bentuk instrumen, dan butir-butir instrumen yang akan dipakai untuk mengukur indikator yang telah dirumuskan.

Hasil penilaian sangat diperlukan dalam melakukan evaluasi, hal ini terkait dengan kebutuhan untuk membuat keputusan, seperti dinyatakan oleh Brown (2004) bahwa evaluasi adalah kegiatan melakukan keputusan berdasarkan informasi yang telah diperoleh dalam penilain tersebut. Gay (2000) menyatakan evaluasi menentukan tingkat ketercapaian tujuan melalui proses yang sistematis mulai dari mengumpulkan data, menganalisis dan memberikan penilaian. Evaluasi juga memberikan keputusan melalui proses sistematis dari mengumpulkan data, menganalisis, dan mengambil keputusan.Berdasarkan pendapat tersebut, maka evaluasi dapat diartikan sebagai kegiatan melakukan keputusan dengan mempertimbangkan data-data atau bukti yang telah diambil sebelumnya sehingga ada keterkaitan antara kegiatan penilaian dengan evaluasi.

Grounlund (1981)mengungkapkan bahwa penilaian dan evaluasi saling terkait karena hasil penilaian merupakan salah satu sumber informasi yang sangat penting dalam lingkungan belajar. Oleh karena itu hasil penilaian dapat dipakai sebagai dasar untuk mengevaluasi program pembelajaran sesuai dengan harapan, dalam arti mampu menunjang tercapainya kompetensi lulusan yang ditargetkan.Tercapainya kompetensi lulusan tidak hanya tergantung pada program pembelajaran, namun terkait langsung dengan asesmen seperti yang diungkapkan oleh Johnson dan Johnson (2002) bahwa asesmen dapat dilakukan tanpa evaluasi tetapi tidak dapat mengevaluasi di luar asesmen dan evaluasi dilakukan sesaat sedang asesmen secara terus menerus.

Asessmen merupakan suatu proses pengumpulan informasi tentang apa yang diketahui dan apa yang dapat dikerjakan siswa (Hart,1994). Menurut Linn dan Gronlund (1995) penilaian adalah istilah umum yang melibatkan semua rangkaian prosedur yang digunakan untuk mendapatkan informasi tentang hasil belajar siswa atau peserta didik. Sedang menurut Brown (2004) penilaian sebagai suatu proses yang secara berkelanjutan dilakukan untuk mengumpulkan informasi tentang pembelajaran siswa dengan menggunakan berbagai macam prosedur. Berdasarkan uraian tersebut dapat disimpulkan bahwa asesmen merupakan kegiatan mengumpulkan informasi tentang kemajuan belajar siswa dengan menggunakan bermacam-macam prosedur, seperti tes formal, inventori, checklist, asesmen diri, portofolio, proyek dan kegiatan lainnya.

\section{Hakekat Asesmen Autentik dan Penerapannya dalam Pembelajaran Biologi}

Akuntabilitas merupakan salah satu prinsip pelaksanaan penilaian yang dapat dipertanggungjawabkan, baik dari segi teknik, prosedur, maupun hasilnya. Oleh karena itu, penilaian dilakukan dengan mengikuti prinsip-prinsip keilmuan dalam penilaian sehingga keputusan yang diambil memiliki dasar yang objektif. Penilaian secara autentik dalam pembelajaran dilakukan sebagai upaya untuk mendapatkan 
dan memutuskan hasil belajar secara akurat. Hart (1994) menyatakan asesmen autentik merupakan suatu penilaian yang dilakukan melalui penyajian atau penampilan oleh siswa dalam bentuk pengerjaan tugas-tugas atau berbagai aktivitas tertentu yang langsung mempunyai makna pendidikan.

Menurut Corebima (2004) berbicara tentang asesmen autentik, sebenarnya juga berbicara tentang asesmen non-autentik; karena "lawan" dari asesmen autentik adalah asesmen non-autentik, karena sudut pandangnya memang demikian. Oleh karena itu tidak tepat membayangkan lawan dari asesmen autentik adalah asesmen yang menggunakan alat paper and pencil test; tidak semua paper and pencil secara otomatis bersifat non-autentik. Demikian juga dengan traditional test tidak serta merta menjadi alat ukur pada asesmen non-autentik, sehingga traditional assessment tidak sekaligus tergolong asesmen non-autentik.

Perbandingan antara asesmen tradisional dan asesmen autentik secara rinci perbedaannyua disajikan pada Tabel 0.1 . Uraian ini memberikan pemahaman bahwa asesmen autentik harus melibatkan siswa di dalam tugas-tugas autentik yang bermanfaat, penting, dan bermakna. Selain itu asesmen autentik merupakan bagian tidak terpisahkan dari pembelajaran di dalam kelas, terintegrasi dalam setiap jenis pembelajaran yang digunakan guru.

Tabel 1. Perbandingan Asesmen Autentik dan Asesmen Tradisional

\begin{tabular}{ll}
\hline \multicolumn{1}{c}{ Asesmen Tradisional } & \multicolumn{1}{c}{ Asesmen Autentik } \\
\hline Periode waktu tertentu & Waktu ditentukan oleh guru dan siswa \\
Mengukur kecakapan tingkat rendah & Mengukur kecakapan tingkat tinggi \\
Menerapkan drill dan latihan & Menerapkan strategi-strategi kritis dan kreatif \\
Memiliki perspektif sempit & Memiliki perspektif menyeluruh \\
Mengungkapkan fakta & Mengungkap konsep \\
Menggunakan standar kelompok & Menggunakan standar individu \\
Bertumpu pada ingatan (memorisasi) & Bertumpu pada internalisasi \\
Hanya satu solusi yang benar & Solusi yang benar banyak \\
Mengungkap kecakapan & Mengungkap proses \\
Mengajar untuk ujian & Mengajar demi kebutuhan
\end{tabular}

(Sumber: Fraze dan Rudnitski, 1995 dalam Corebima, 2004:9)

Muller (2003) membedakan asesmen autentik dengan asesmen tradisional melalui penggambaran gerak titik kontinum dari asesmen tradisional (kiri) menuju asesmen autentik (ke kanan). Pada asesmen tradidional siswa diberi sejumlah pilihan (seperti a, b, c, d; benar-salah) dan hanya mencari jawaban yang benar saja. Berbeda dengan asesmen autentik yang meminta siswa untuk mendemonstrasikan apa yang dipahami baik pengetahuan, keterampilan, dan kompetensi apapun yang mereka miliki sehingga lebih aplikatif dan bermakna. Prinsip asesmen ini sangat tepat digunakan dalam pembelajaraan yang menuntut siswa tidak sekedar memahai pengetahuan tetapi diharapkan dpat memecahkan masalah kehidupan sehari-hari seperti halnya karakter pembelajaran Biologi. Biologi merupakan salah satu dari cabang ilmu pengetahuan yang mempelajari tentang makhluk hidup dan lingkungannya. Mempelajari biologi tidak sekedar mendapatkan pengetahuan tentang makhluk hidup, namun juga mendapat pengetahuan tentang metode mempraktekkan ilmu pengetahuan tersebut. Pengetahuan yang diperoleh diharapkan dapat membantu untuk memecahkan masalah guna meningkatkan kesejahteraan hidup manusia. Dalam mencapai tujuan tersebut memerlukan metode yang sistematis yang disebut metode ilmiah. Penerapaan metode ilmiah dalam pembelajaran khususnya pembelajaran IPA 
dapat digunakan dalam pendekatan keterampilaan proses (PKP).

Demikian juga dengan Pendekatan Keterampilan Proses memandang sains sebagai proses ilmiah dan pendidikan sains adalah pelatihan keterampilan proses sains yang biasa digunakan oleh para ilmuwan kepada siswa. Oleh karena itu siswa harus memperoleh pengalaman ilmiah untuk memperoleh produk ilmiah seperti konsep, prinsip dan hukum. Belajar dengan menggunakan PKP mempunyai cara pandang bahwa belajar adalah mempelajari bagaimana para ilmuwan belajar sains atau diungkapkan dengan "learning how to learn". Dalam mempelajari sains, para ilmuwan menggunakan keterampilan yang disebut

Tradisional Selecting response Contrived Recall/Recognition Teacher-structured Indirect Evidence
Authentic Performing a task Real-life Construction/Application Student-structured Direct Evidence

Gambar 0.1 Gerak Titik Kontunum Asesmen Tradisional

\section{ke Asesmen Autentik}

Hart (1994) menjelaskan bahwa asesmen autentik memberikan kesempatan kepada siswa untuk melaksanakan tugastugas autentik yang menarik, bermanfaat, dan relevan dengan kehidupan siswa. Tugas ini dapat menjadikan siswa inovatif dan kreatif karena memiliki kesempatan untuk mengembangkan diri, menumbuhkan sikap yang lebih positif terhadap sekolah, kegiatan belajar dan dirinya sendiri. Sikap positif akan mempengaruhi pada pola berpikir siswa, sehingga dapat meningkatkan prestasi yang positif. Hal ini sesuai pendapat Marzano et. al (1993) bahwa penilaian autentik mengandung tiga unsur inovasi dalam bidang penilaian. Pertama, tidak mengukur ketercapaian tujuan pembelajaran yang tradisional, tetapi lebih menekankan pada kemampuan nyata subyek belajar. Kedua, bersifat menyeluruh, mengembangkan seluruh kemampuan subyek belajar melalui kegiatan pembelajaran menurut paham konstruktivisme. Ketiga, tidak menggunakan sistem tes tradisional tetapi menggunakan berbagai cara.

Dengan demikian asesmen autentik mengubah peran siswa dalam proses asesmen, dari sifat pasif menjadi partisipan aktif, siswa aktif berkolaborasi untuk bekerjasama dan dapat berpartisipasi dalam mengevaluasi kemajuannya. Asesmen autentik dapat mengaktifkan pembelajaran melalui banyak cara sementara tes terstandar bersifat ekskusif dan sempit. Rivers (2001), Schraw \& Dennison (1994) melaporkan bahwa para siswa yang terampil melakukan asesmen terhadap diri sendiri sadar akan kemampuannya, bertindak lebih strategis dan lebih baik dibanding mereka yang tidak terampil. Asesmen autentik dapat mempertajam keterampilan berpikir tingkat tinggi pada saat mereka menganalisis, 
mensisntesis, mengidentifikasi masalah, menciptakan pemecahan, dan mengikuti keterkaitan sebab akibat (Johnson, 2002).

Penerapan tahapan keterampilan dalam PKP menuntut asesmen yang sesuai, maksudnya kegiatan yang ddilakukan harus diukur dengan instrumen yang sesuai, tepat, efektif agar tujuan pembelajar tercapai dan siswa benar-benar belajar sains (Biologi) dengan benar. Kompetensi yang diharapkan dalam belajar Biologi Ketrampilan proses sains dibedakan menjadi ketrampilan proses dasar dan ketrampilan proses terintegrasi. Pembedaan keterampilan ini perlu dicermati karena sebenarnya keterampilan berbeda menghendaki jenis asesmen yang sesuai dengan target keterampilan yang dikehendaki.

Tabel 2. Analisis Ketrampilan Proses Sains dan Aspek Tagihannya

\begin{tabular}{|c|c|c|}
\hline $\begin{array}{l}\text { Keterampilan } \\
\text { Proses }\end{array}$ & deskripsi & Aspek task (tagihan) \\
\hline $\begin{array}{c}\text { DASAR } \\
\text { Observasi }\end{array}$ & $\begin{array}{c}\text { Pengidentifikasian dan pemberian } \\
\text { nama ciri-ciri benda dan kejadian } \\
\text { dalam dunia fisik }\end{array}$ & $\begin{array}{l}\text { Megidentifikasi dan memberikan nama } \\
\text { ciri benda }\end{array}$ \\
\hline Klasifikasi & $\begin{array}{c}\text { Mengatur benda, kejadian atau } \\
\text { informasi dengan metode atau } \\
\text { sistem tertentu }\end{array}$ & Mengklasifikasikan benda atau kejadian \\
\hline Pengukuran & $\begin{array}{l}\text { Membandingkan suatu obyek dari } \\
\text { dimensi yang tidak diketahui } \\
\text { dengan dimensi yang diketahui }\end{array}$ & Melakukan pengukuran suatu obyek \\
\hline Komunikassi & $\begin{array}{c}\text { Menyampaikan ide melalui } \\
\text { hubungan sosial }\end{array}$ & komunikasi, diskusi-presentasi \\
\hline Pengambilan Kesimpulan & $\begin{array}{l}\text { Membuat kesimpuian } \\
\text { berdasarkan reasoning untuk } \\
\text { menjelaskan satu set observasi }\end{array}$ & Menyusun kesimpulan \\
\hline Prediksi & $\begin{array}{l}\text { Meramalkan kejadian di masa } \\
\text { datang berdasarkan bukti nyata }\end{array}$ & Kemampuan menyusun ramalan \\
\hline $\begin{array}{l}\text { Penggunaan hubungan } \\
\text { tempat waktu }\end{array}$ & $\begin{array}{l}\text { Menggunakan bentuk geometri } \\
\text { untuk pengamatan }\end{array}$ & Kemampuan menghubungkan \\
\hline Penggunaan angka & $\begin{array}{c}\text { Mengaplikasikan hukum atau } \\
\text { rumus matematik untuk } \\
\text { menghitung angka }\end{array}$ & Keterampilan mengaplikasikan \\
\hline Identifikasi variabel & $\begin{array}{l}\text { Mengenal karakteristik obyek } \\
\text { atau kejadian yang bersifat } \\
\text { konstan atau berubah }\end{array}$ & Kemampuan mengidentifikasi \\
\hline
\end{tabular}

TERINTEGRASI

Penyusunan Hipotesis

Pengontrolan variabel

$$
\text { Investigasi }
$$

Membuat definisi operasional

Eksperimentasi
Membuat pernyataan yang dipercaya benar tentang satu kejadian

Mengubah suatu obyek atau kondisi sementara yang lain dibiarkan konstan

\begin{tabular}{ccc}
\hline Investigasi & $\begin{array}{c}\text { Mencari data dalam suatu situasi } \\
\text { belajar diskovery }\end{array}$ & Kemampuan melakukan investigasi \\
\hline $\begin{array}{c}\text { Membuat definisi } \\
\text { operasional }\end{array}$ & $\begin{array}{c}\text { Menciptakan definisi suatu istilah } \\
\text { sesuai dengan konteksnya }\end{array}$ & $\begin{array}{c}\text { Kemampuan membuat definisi } \\
\text { operasional }\end{array}$ \\
\hline Eksperimentasi & $\begin{array}{c}\text { Merancang dan melaksanakan } \\
\text { eksperimentasi dengan } \\
\text { melibatkan semua keterempilan } \\
\text { proses terintegrasi }\end{array}$ & Merancang eksperimen \\
& & \\
\hline
\end{tabular}

Kemampuan menyusun hipotesis

Kemampuan melakukan pengonrolan

(1) 
mengukur kognitif saaja karena cukup banyak kompetensi yang dituntut pada siswa terkait sikap dan psikomotor. Jelas sekali dibutuhkan asesmen autentik yang dpat menjadikan siswa aktif berkolaborasi, kerjasama, dan berpartisipasi dalam mengevaluasi kemajuannya, hal ini mengharuskan siswa menjadi performer efektif dengan pengetahuan yang didapatkannya. Tes tradisional cenderung hanya menampakkan tentang apakah siswa dapat mengenal, mengingat atau "memahami" apa yang telah dipelajarinya di luar konteks yang ada. Menurut Marzano (1993), asesmen kinerja dapat memberikan suatu sarana yang efektif dalam mengukur kemampuan yang sulit atau yang tidak dapat dilakukan paper and penciltest. Kemampuan yang dapat diukur, seperti kemampuan untuk berkomunikasi, memecahkan masalah, dan menggunakan keahlian untuk berpikir kritis.

Menurut pendapat tersebut, maka asesmen kinerja membantu siswa melakukan metakognitif yaitu mengarahkan bagaimana cara siswa belajar. Hal ini tidak dapat dilakukan bila menggunakan paper and pencil test. Ibrahim (2002) menyatakan tidak ada paper and pencil dengan gradasi jawaban benar atau salah dapat mengevaluasi kinerja, guru seharusnyalah merubah cara mengajar dengan mengubah bentuk asesmen, karena jika guru mengubah cara mengases siswa, maka guru pun harus merubah cara mengajar dan bagaimana siswa belajar (Hart, 1994). Dengan demikian asesmen performance didesain untuk membantu siswa "belajar bagaimana belajar".

Menurut Nur (2001) prinsip sistem penilaian berkelanjutan adalah menilai semua kompetensi dasar, menganalisis hasil penilaian dan melakukan tindak lanjut yang berupa program perbaikan atau program pengayaan, dengan agar asesmen yang digunakan dapat dikategorikan autentik sebaiknya memiliki ciri-ciri sebagai berikut: 1) mengukur pengetahuan dan keterampilan siswa; 2) mempersyaratkan penerapan pengetahuan dan keterampilan; 3) penilaian terhadap produk atau kinerja; 4) tugas-tugas kontekstual dan relevan; 5) proses dan produk, yang dapat diukur.

Sesuai hasil penelitian Mary dan Issac (2006) menjelaskan penilaian berkelanjutan dapat meningkatkan hasil belajar siswa secara kuantitatif dan kualitatif. Secara kuantitatif meningkatkan skoring nilai, sedangkan secara kualitatif dapat meningkatkan motivasi, minat dan kebiasaan belajar. Respons siswa kelompok pandai menjadi beruntung dengan nilai bagus, sedang kelompok rendah kurang menyukai karena sulit serta jenuh sehingga nilainya cukup jika dibanding kelompok pandai.

Berdasarkan uraian di atas maka guru harus berupaya agar pembelajaran berlangsung autentik harus selalu mengkaitkan materi dan tugas siswa dengan permasalahan dalam kehidupan sehari-hari. Hal ini dilakukan agar sejalan dengan tujuan asesmen autentik, dengan tetap memperhatikan prinsip-prinsip asesmen. Inovasi dalam pendidikan akan tercapai bila prinsip-prinsip dalam pembelajaran tetap diterapkan dengan baik.

Salah satu prinsip asesmen adalah assessment is instruction yaitu Assessment and teaching can be one and the same, melalui kelas autentik berbasis asesment, guru, siswa, dan yang lainnya dapat melihat pembelajaran riil dan perkembangan yang terjadi (Stiggins, 1994) Asesmen yang baik, dalam hal ini asesmen autentik dapat meningkatkan pengajaran, dan dengan pengajaran yang baik dapat meningkatkan prestasi siswa. Menurut Marzano (1993), asesmen berpengaruh langsung dan tidak langsung terhadap belajar, secara langsung asesmen memberikan feedback untuk belajar secara efektif, sedang pengaruh tidak langsungnya adalah pengajaran umumnya cenderung pada apa yang diajarkan dan mempengaruhi apa yang dipelajari.

Sejalan dengan pendapat di atas, maka asesmen merupakan bagian dari 
pembelajaran yang tidak terpisahkan, sebagaimana dikemukakan Gronlund (1998) bahwa hubungan antara pembelajaran dengan asesmen seperti diuraikan berikut: 1) Pembelajaran menjadi efektif apabila langsung ke arah penyelesaian hasil belajar dengan memberi tanda, metode dan bahan pembelajaran selaras dengan karakteristik dan kebutuhan siswa, pembelajaran dirancang sesuai dengan karakteristik dan kebutuhan siswa, pembelajaran diputuskan didasarkan pada informasi yang berarti, saling berkait dan relevan, kemajuan belajar siswa diinformasikan secara periodik, remidi sebagai tindakan bagi siswa yang belum berhasil dalam belajar, pembelajaran efektif adalah secara periodik mengulang, dan pada waktu yang akan datang hasil belajar dan pengajaran dimodifikasi sesuai dengan yang dibutuhkan; 2) penilaian menjadi efektif ketika dirancang dengan jelas untuk menandai hasil belajar yang berlangsung pada waktu tertentu, pembawaan dan fungsi penilaian selaras dengan hasil yang dinilai, penilaian dirancang sesuai dengan karakteristik siswa yang relevan dan terbuka untuk setiap orang, penilaian untuk melengkapi informasi yang berarti, berhubungan dan relevan, serta perlengkapan dibuat untuk memberi siswa umpan balik lebih awal hasil penilaian. Dengan demikian asesmen autentik harus dipahami dan dilakukan sebagai bagian yang tidak terpisahkan dari proses pembelajaran.

Prinsip dasar tugas-tugas asesmen dalam pembelajaran yaitu asesmen merupakan: 1) bagian dari perencanaan yang efektif; 2) menitikberatkan pada bagaimana siswa belajar; 3) pusat dari pelatihan di kelas; 4) kunci keterampilan professional; 5) sesitif dan konstruktif; 6) meningkatkan motivasi; 7) mendukung pencapaian tujuan; 8) membantu siswa mengetahui bagaimana memperbaiki; 9) mengembangkan kemampuan melalui penilaian diri; 10) mengembangkan pendidikan (ARG: 2002).Tentunya prinsip asesmen ini jika diterapkan dengan baik dalam pembelajaran akan memberikan hasil sesuai tuuan yang diharapkan, sebagaimana yang telah ditemukan oleh Pantiwati (2011) bahwa siswa di sekolah kategori rendah yang menggunakan asesmen autentik kemampuan kognitif, berpikir kritis, dan berpikir kreatifnya sama dengan siswa di sekolah kategori tinggi yang tidak menggunakan asesmen aautentik. Hasil ini membuktkan bahwa asesmen autentik dapat meningkatkan kemampua kognitif, berpikir kritis, dan berpikir kreatif dengan tetap memperhatikan karakter siswa.

Adapun bentuk tugas-tugas tersebut meliputi: 1) portofoio, 2) pembuatan jurnal/paper, 3) simulasi, 4) membuat desain dan presentasi, 5) observasi kritis, 6) mengerjakan proyek individu dan kelompok, 7) melaporkan hasil studi lapangan, 8) melakukan kegiatan pemecahan masalah, 9) membuat peta konsep, dan sebagainya. Selanjutnya strategi-strategi asesmen yang digunakan dalam melakukan asesmen berkelanjutan adalah sebagai berikut: asesmen kinerja (Performance Assessment), observasi (Observation), penggunaan pertanyaan (Questioning), Presentasi (Presentation), diskusi (Discusions), Eksperimen/demonstrasi

(Experiments/demonstration),

Projek/Pameran (Projects/Exhibition), Bercerita (Story or text retelling), Investigasi/penyelidikan (Investiga-tion), Portofolio (Portofolio), Jurnal (Journal), Wawancara (Interview), Konferensi, Evaluasi diri oleh siswa (Self Evaluation)(O'Malley and Pierce, 1996).

\section{SIMPULAN DAN SARAN}

Biologi merupakan salah satu cabang sains yang mempunyai karakter dalam mempelajarinya tidak cukup pengetahannya saja tetapi menuntut untuk diterapkan dalam kehidupan sehari-hari sehingga membantu manusia mendapaatkan kesejateraan. Pembelajarn yang digunakan dalam Biologi 
menggunakan pendekatan keterampilan proses, sehingga siswa tidak cukup dinilai pengetahuannya saja yaitu dari domain kognitif. Guru membutuhkan asesmen autentik yang dapat melakukan penilailan secara holistik meliputi kognitif, afektif, dan psikomotor. Jenis asesmen autentik sangat bervariasi, oleh karena itu guru perlu menyesuaikan apa kriteria dan aspek yang akan diukur agar penialaian bermakna sehingga dapat menggambarkan kemampuan siswa. Sekolah dan pemerintah hendaknya memberikan fasilitas bagi guru untuk melakukan penilaian secara autentik baik berupa fisik material atau kebijakan.

\section{DAFTAR PUSTAKA}

ARG. 2002. Assessment for Learning: 10

Principles. University of Cambridge: Assessment Reform Group.

Brown, Janet. H. S. \& Richard, J. 1996.Assessing Hands-On Science.California: Corwin Press, Inc.

Corebima. 2004. Pemahaman Tentang Asesmen Autentik. Makalah disijikan pada Pelatihan PBMP pada Pembelajaran Bagi Para Guru Sains Biologi dalam Rangka RUKK VA, 9-10 Juli 2004.

Grounlund, N.E. 1981. Measurement and Evaluation in Teaching. New York: MacMilan Publishing CO. Inc.

Gronlund, G. 1998. Portfolios as an Assessment Tool: is Collection of Work Enough? Young Children, 53(3), 4-10.

Hart, Diane. 1994. Authentic Assessment A handbook for Educators. California, New York: Addison Wesley Publishing Company

Johnson, D.W. 2002.Meaningful Assessment A Manageable and Cooperatve Process. USA: Allyn and Bacon
Johnson, D.W \& Johnson, R.T. 2002. Meaningful Assessment. Arlington Street Boston: Ally \& Dacon A Pearson Education Company

Marry, J.S., \& Issac, B. 2006. Observation of Assessment Effects and Student Perception in Higher Education. Makalah disajikan pada International Conference on Measurement and Evaluation in Education tanggal13-15Pebruari 2006 di School of Educational Studies Universiti Sains Malaysia Penang-Malaysia

Marzano, R. J. (1993). Designing a New Taxonomy of Educational Objectives. Thousand Oaks, CA: Corwin Press.

Mueler John, 2003, What is Authentic Assessment?, http://jonathan.mueller.faculty.noctr 1.edu/toolbox/whatisit.htm Diakses: 24 September 2005

Nur, M. 2000. Strategi-strategi Belajar. Surabaya: UNESA Press.

Pantiwati, Yuni. 2011. Pengaruh Jenis Asesmen Biologi dalam Pembelajaran TPS terhadap Kemampuan Konitif, Kritis, dan Kreatif. Prosiding Seminar Nasional Pendidikan Asesmen Otentik dalm Implementasi Pembelajaran Aktif dan Kreatif. Bandar Lampung, Januari, 29-30 2011.

Pantiwati, Yuni. 2013. Profil Sistem Penilaian dalm Pembeljaran Biologi. Prosiding Seminar Nasional Pendidikan Sains. Iperan Sains dalam Abad 21. Surabaya, Januari, 2013.

Stiggins, RJ. 1994. Student Centered

Classroom Assessment. New York: maxwell Macmillan International Simon \& Schuster Company 
Umar, Jahja.2004. Pengembangan Sistem Penilaian Untuk meningkatkan Mutu Pendidikan Nasionan di Era Global. Makalah disajikan pada Seminar Nasional Rekayasa Sistem Penilaian dalam Rangka Meningkatkan Kualitas Pendidikan. Himpunan Evaluasi Pendidikan Indonesia (HEPI) tanggal 26 dan 27 Maret 2004 di Yogyakarta
Wierma, William and Stephen G. Jurs. 1990. Educational Measurement and Testing. Boston: Allyn and Bacon. Zamroni. 2004. Pengembangan Sistem Penilaian Pendidikan Menengah yang Menerapkan KBK dalam Kerangka Otonomi Daerah. Makalah disajikan pada Seminar Nasional Rekayasa Sistem Penilaian dalam Rangka Meningkatkan Kualitas Pendidikan. Himpunan Evaluasi Pendidikan Indonesia (HEPI) tanggal 26 dan 27 Maret 2004 di Yogyakarta 